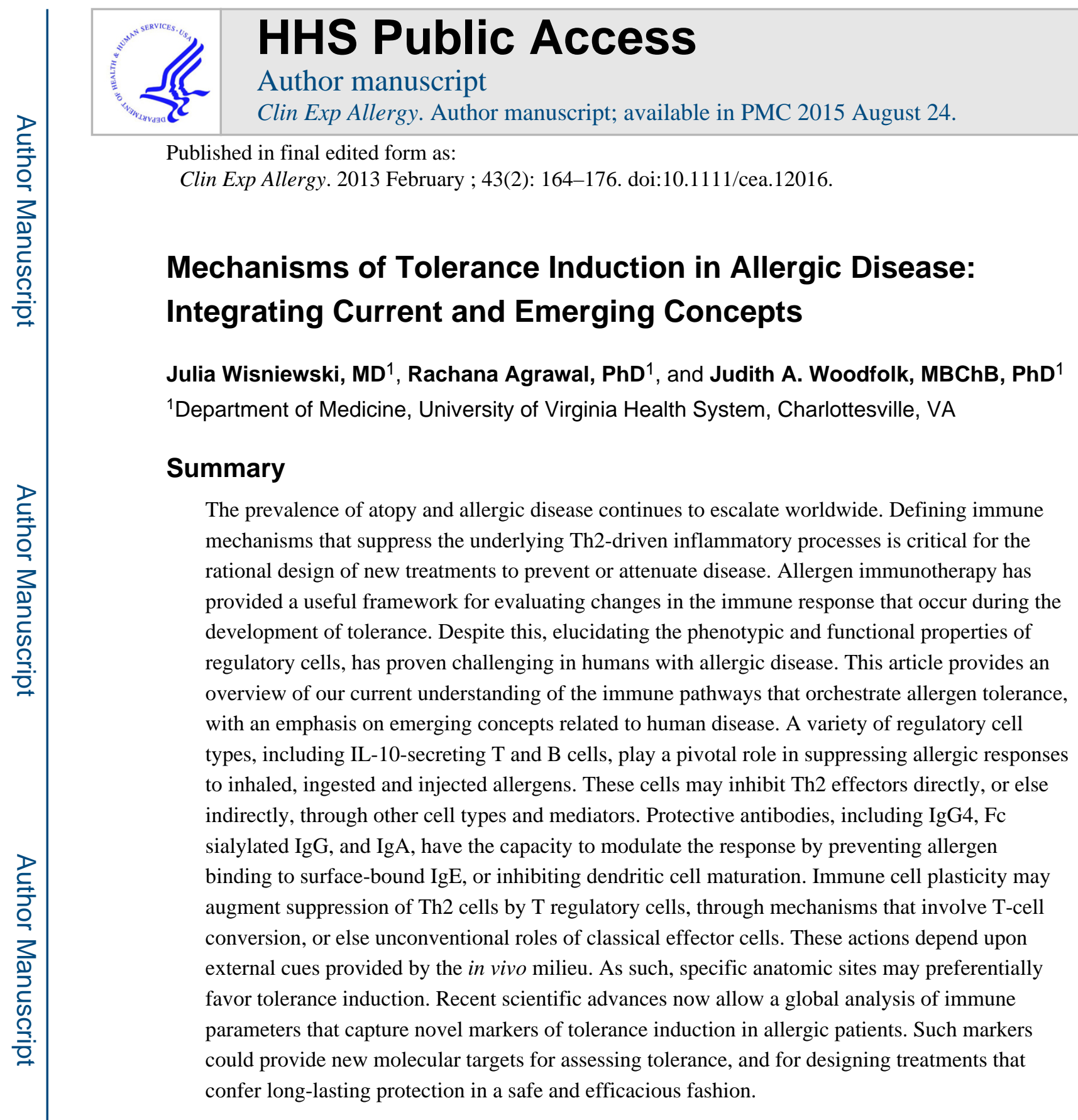

\title{
Introduction
}

Studies on allergen tolerance in both humans and animal models abound. Despite this, the immune mechanisms that govern this process in humans remain enigmatic. This can be attributed, in large part, to the lack of reliable surface markers expressed on regulatory cells in man, the plasticity of these cells, and limitations of in vitro experimental systems that fail to mimic the complex regulatory networks operating in vivo. An exhaustive review of the assortment of regulatory cells is beyond the scope of this article. Instead, the objective is to integrate current knowledge of mechanisms of allergen tolerance in humans with emerging

Corresponding author: Judith A. Woodfolk, MBChB, PhD, Allergy Division, PO Box 801355, University of Virginia Health System, Charlottesville, VA 22908-1355. Tel: 434-924-1293; Fax: 434-924-5779; jaw4m@ virginia.edu. 
concepts. Aspects highlighted include recent discoveries in regulatory cell types and cell plasticity, and their relevance to regulatory networks underlying allergen tolerance.

\section{What is Allergen Tolerance?}

In 1953, Peter Medawar and colleagues reported in the journal Nature on the discovery of "actively acquired tolerance" of foreign cells, stemming from their seminal work on tissue transplantation [1]. By injecting fetal mice (strain CBA) with cells from a different donor strain (strain A), it was observed that the immune system could be manipulated to prevent later rejection of a skin graft from strain A mice. In this context, immune tolerance was defined as "a state of indifference or non-reactivity towards a substance that would normally be expected to excite an immunological response." Burnet proposed that it would be possible to induce tolerance to more remotely foreign antigens, and that tolerance encapsulates the following features: (1) an alteration of the host...not antigenic adaptation of the grafted cells; (2) a systemic and specific immune response; (3) continued presence of the antigen; (4) varying degrees of the response (ie. not an "all or nothing" response); and (5) a requirement for lymphoid cells. Arguably, all of these features can be applied to allergen tolerance.

At the simplest level, allergen tolerance can be considered as a non-pathogenic immune response to allergen that is mediated by an active process It develops during allergen immunotherapy (IT), and can be attained through a variety of different routes including the skin, as is the case for conventional IT using allergen extracts, and rush IT with bee venom. Similarly, there is mounting data from clinical trials of both sublingual IT and oral IT, to support the development of protective responses at mucosal sites. In food allergy, a distinction has been drawn between desensitization (an increase in antigen dose required to elicit symptoms, arising from a transient altered immune response) and tolerance (the ability to ingest food without symptoms once treatment has ceased, owing to persistent changes in the immune response) [2,3]. Allergen tolerance also occurs upon natural exposure to high levels of allergen in the environment, as typified by the modified Th2 response to cat allergen [4]. It is assumed that this reflects high dose tolerance through the respiratory tract. In all cases, regardless of the mode of tolerance induction, it is likely that similar fundamental mechanisms apply.

Despite the ubiquitous nature of allergens, the majority of exposed subjects fail to mount an allergic response. Whether this represents a form of tolerance arising from an active control mechanism, or else a state of non-responsiveness, remains open to debate. While some allergens (eg. cat) can induce a characteristic protective immune response, others (eg. mite) do not appear to do so. Nonetheless, the ability to detect regulatory cells and invoke T cell responses to diverse allergens in cultures from non-allergic subjects, provides convincing evidence for involvement of active processes. These responses are likely governed by the numerous and varied genetic and environmental determinants that protect against allergy.

Allergen IT has proven effective for the treatment of allergic rhinitis and provides a useful model for studying the development of tolerance. Hallmarks of allergen tolerance induced by IT include the following: (1) increases in IgG1, IgG4 and IgA antibodies; (2) decreased 
IgE; (3) a Th2 to Th1 shift along with a decrease in T cell proliferation and cytokine response to allergen; and (4) increased T regulatory (Treg) cells along with enhanced production of IL-10 and TGF- $\beta$. There is substantial evidence that IL-10 governs many of these changes through suppression of Th2-driven processes.

\section{T Regulatory Cells: Form and Function}

\section{Induction of Treg Cells}

Much of the focus on mechanisms of allergen tolerance has spotlighted the role of Treg cells. These cells act to suppress effector $\mathrm{T}$ cells involved in allergic inflammatory processes through effects on T-cell differentiation and amplification. This may occur through direct Tcell suppression, or else indirectly through inhibition of dendritic cells (DCs). Until recently, those Treg cells most often implicated in allergen tolerance in humans were defined based on expression of surface CD25 (IL-2Ra) and the transcription factor Foxp3, with or without production of IL-10 or TGF- $\beta$. Despite the evidence for Treg cell induction, it remains unclear how these cells are generated. Data in both in vitro human-based systems and in vivo mouse models indicates a requirement for pro-inflammatory signals such as LPS and epithelial-derived cytokines (eg. IL-25, IL-33 and TSLP), for the induction of Th2-driven allergic inflammatory processes [5-12]. During allergen IT, it is thought that a lack of these pro-inflammatory signals, or else the presence of alternate activation signals, results in a partially mature or tolerogenic phenotype in DCs, which in turn favors Treg cell induction. Once induced, Treg cells can act to further suppress DCs, or else drive induction of IL-10producing DCs, which can then further enhance Treg cell production [13-15].

\section{Challenges to Understanding Mechanisms of Action of Tregs in Humans}

The general view is that Treg cells suppress a variety of effector T-cell subtypes involved in the pathogenesis of allergic disease, including Th2, Th1, Th17 and Th9 cells. A role for Treg cells in suppressing mast cells, eosinophils and basophils, is also emerging; however, most experimental evidence comes from animal models. While Treg cells can directly inhibit mast cells in mice [16], it is not clear whether Treg cells act similarly in humans. Instead, it has been inferred that the suppressive effects of Treg cells on mast cells and granulocytes are mediated indirectly through suppression of Th2 cytokines. Beyond these cell types, IL-10 selectively enhances IgG4 production by human B cells, and IL-10-producing Treg cells can induce IgG4 through a variety of molecules including IL-10 and TGF- $\beta$, as well as the GITR-GITRL pathway $[17,18]$. These observations provide a plausible mechanism for Treg cell-mediated enhancement of IgG4 antibody production during allergen IT.

While a broad array of molecules have been implicated in Treg cell-mediated suppression in vitro [19], it has been difficult to validate these pathways in vivo in humans. Human Treg cells are highly heterogeneous and difficult to identify. Moreover, rigorous analysis of the functional properties of these cells has been hindered by the lack of a reliable surface marker. Natural Treg cells are arguably the best characterized Treg type in humans. These cells, which are selected by high avidity interactions in the thymus, constitutively express high levels of CD25 and the transcription factor Foxp3 (Figure 1) [20]. By contrast, adaptive Treg cells arise from naïve conventional $\mathrm{CD}^{+} \mathrm{T}$ cells in the periphery following antigen 
encounter. These include IL-10-secreting Tr1 cells and TGF- $\beta$-producing Th3 cells. In humans, it is not clear whether natural Treg cells can become IL-10-expressing Treg cells, nor how natural Treg cells relate to $\operatorname{Tr} 1$ cells. In animal models, Foxp $3^{+}$Treg cells can differentiate outside the thymus upon antigen recognition, and these cells can control allergic inflammation [21-25]. Thus, Foxp $3^{+}$Treg cells involved in allergen tolerance in humans likely comprise a mixture of natural Treg cells and those induced in the periphery. Other Foxp $3^{+}$Treg-like cell types identified in humans include those that produce IL-17 [26], and those that are induced ex vivo from naïve $\mathrm{CD} 4^{+} \mathrm{T}$ cells by TGF- $\beta$ in combination with other factors [27-29]. However, the suppressive capacity of these latter cell types remains has been questioned (Figure 1).

Studying Treg cells in humans is further confounded by the blurred distinction between these cells and effector $\mathrm{T}$ cells in the context of active inflammatory disease. Unlike cells in mice, activated effector T cells in humans transiently express Foxp3 [30-32]. Expansion of the $\mathrm{CD} 25^{+} \mathrm{Foxp}^{+}$subset is a prominent feature of circulating $\mathrm{CD} 4^{+} \mathrm{T}$ cells in highly atopic subjects, and this likely reflects the presence of both Treg cells and activated effector cells [33]. Recent work indicates that, unlike activated effector T cells, Foxp3 ${ }^{+}$Treg cells maintain Foxp3 expression over rounds of cell division. This has been attributed to DNA demethylation within a conserved noncoding region in the Foxp3 gene [34-36]. Analyzing methylation status at the Foxp 3 locus should prove useful for clarifying Treg cells induced during allergen IT.

\section{The Role of IL-10 in Allergen Tolerance}

\section{Immunotherapy and IL-10}

Of all the molecules implicated in T-cell suppression associated with allergen tolerance, IL-10 remains the most robust. In grass pollen IT, increases in allergen-stimulated IL-10 production coincide with inhibition of late skin responses ( 2 to 4 weeks), but precede the rise in IgG4 antibodies and clinical effects [37]. This suggests that IL-10 sets the stage for the immune sequelae that ensue during IT. Work by Akdis and colleagues in the late 1990's established a critical role for IL-10 in the rapid induction of T-cell tolerance to the major bee venom allergen, phospholipase $\mathrm{A}_{2}\left(\mathrm{PLA}_{2}\right)$, during rush IT [38]. The same group recently reported the capacity for allergen-specific Th1 or Th2 cells to "switch" to IL-10-secreting cells in high dose tolerance induced through the skin, by a process involving a direct effect of histamine. A variety of other molecules, including CTLA-4 and PD-1, were also implicated in the development of tolerance, suggesting involvement of multiple immune pathways [39].

The ability for IL-10 secretion to supplant Th2 cytokine production in T effector cells provides one possible mechanism for diminished Th2 responses observed during allergen IT. By contrast, other studies indicate a role for apoptosis or deletion of Th2 cells [40, 41]. Most recently, preferential deletion of pathogenic terminally differentiated (CD27-) allergen-specific $\mathrm{CD} 4^{+} \mathrm{T}$ cells was reported in patients receiving IT for alder pollen allergy [41]. In that study, T-cell deletion was accompanied by increased production of IL-10 in surviving $\mathrm{CD} 27^{+}$allergen-specific $\mathrm{CD} 4^{+} \mathrm{T}$ cells. In that study, peptide/MHC II tetramers 
were used to monitor allergen-specific $\mathrm{CD} 4^{+} \mathrm{T}$ cells directly ex vivo throughout IT, without the need for in vitro manipulation.

\section{Lessons from a Tolerogenic Allergen}

Our knowledge of the molecular biology of allergens continues to evolve at a rapid pace. The ability for allergens to trigger a broad array of receptors, including toll-like receptors, C-type lectin receptors, and protease activated receptors, is integral to their capacity to promote pathogenic Th2 responses [6, 42-47]. However, it appears that while some allergens, such as the major dust mite allergens Der $\mathrm{p} 1$ and Der $\mathrm{p} 2$, can drive a robust IgE response, others, such as the major cat allergen, Fel d 1, are less potent. Definition of the modified Th2 response to cat allergen over a decade ago, shed new light on these differences [4]. This immune response, which is characterized by high titer IgG and IgG4 antibodies to Fel d 1, in the absence of detectable IgE antibodies or allergic symptoms, is associated with high dose exposure to cat allergen in the environment. This response was proposed to represent a form of high dose respiratory tolerance.

The cat allergen, Fel d 1, shares structural similarity to uteroglobin, a steroid-inducible cytokine-like molecule that is expressed only in mammals [48, 49]. The human homolog, Clara cell $16 \mathrm{kD}$ protein (CC16) produced by lung epithelial cells, inhibits eosinophil migration and suppresses allergen-induced Th2 differentiation [50-52]. Reduced levels of CC16 in the asthmatic lung have been proposed to contribute to airway inflammation [53]. Thus, it is plausible that Fel d 1 constitutes a "tolerogenic allergen", by virtue of its shared structural features with an immunomodulatory human protein. On the other hand, its marked sequence divergence from CC16 at the primary amino acid level may be sufficient to confer allergenicity. Work by several groups supports the presence of an immunodominant "regulatory region" within polypeptide chain 2 of the molecule which binds DR7 molecules and induces IL-10 [54-56]. Notably, $\mathrm{T}$ cell responses to peptides in this region are enhanced in cultures from DR7+ subjects with a modified Th2 response, as well as in cat allergic patients receiving conventional IT [54]. A peptide within this region also binds to two DQ and DP alleles that are common in the population (DQB $1 * 06$ and DPB $1 * 04)$ [56]. Collectively, these findings suggest that chain 2 peptides are good candidates for inclusion in a peptide vaccine for cat allergy.

Administration of Fel d 1 peptides has proven effective for inducing IL-10-mediated tolerance. Since short peptides ( 16-mers) do not cross-link IgE, many of the drawbacks of using whole allergen can be avoided. In a pilot study, Kay and colleagues established the beneficial effects of administering a low dose peptide vaccine in cat-allergic asthmatics, as judged by inhibition of upper and lower airway outcome measurements, including late asthmatic reactions [57]. This vaccine, which comprised peptides spanning both chains of Fel d 1, suppressed T-cell responses to both injected and non-injected peptides, indicating a role for linked epitope suppression [58]. These findings were supported by work in an HLADR1 transgenic mouse model which implicated IL-10-producing "bystander" $T$ cells in this process. Thus, at least for certain allergens, vaccines which contain a limited number of well characterized T-cell epitopes may be sufficient to confer allergen tolerance. 


\section{B Cells and IL-10}

It is well known that mouse B cells have the capacity to secrete IL-10. A subset of these cells, termed B10 cells, display the $\mathrm{CD} 1 \mathrm{~d}^{\text {hi }} \mathrm{CD}^{+} \mathrm{CD} 19^{\text {hi }}$ phenotype and are increased in mouse models of diabetes and autoimmune disease [59-61]. The capacity for these cells to suppress $\mathrm{T}$ cell-dependent inflammatory responses is illustrated by inhibition of contact sensitivity reactions to oxazolone in recipient mice adoptively transferred with $\mathrm{CD} 1 \mathrm{~d}^{\text {hi }} \mathrm{CD}^{+}$ B cells from oxazolone-sensitized mice. This effect is IL-10-dependent and antigen-specific [59]. More recently, IL-10-producing B cells were shown to suppress allergic airway inflammation in mice through induction of pulmonary Treg cells [62]. In humans, B10 cells have been identified within the $\mathrm{CD} 24^{\mathrm{hi}} \mathrm{CD} 27^{+} \mathrm{B}$-cell compartment. These cells negatively regulate monocyte cytokine production in an IL-10-dependent manner [63]. A feature of B10 cells is their ability to rapidly express cytoplasmic IL-10 after ex vivo stimulation. Though these cells, along with their progenitor counterparts (B10pro), represent only a small fraction of blood B cells in healthy subjects $(<5 \%)$, they are expanded in the blood of patients with inflammatory disorders [63]. Recent work has implicated regulatory B cells in the development of tolerance to food allergens in humans; however, it is not clear how these cells relate to human B10 cells $[64,65]$. Expanding analysis of IL-10-expressing cells during allergen IT to include regulatory B cells could provide new insights into IL-10 pathways that underlie allergen tolerance.

\section{Regulatory Cells and the Gut}

Other regulatory cell types that have been implicated in allergen tolerance include TGF- $\beta$ expressing $\mathrm{T}$ and $\mathrm{B}$ cells, as well as $\mathrm{CD} 8^{+}$regulatory $\mathrm{T}$ cells. Arguably, these cell types are most relevant to the development of tolerance to ingested food allergens. Despite this, there is scant supporting data in humans, mainly because these cells are difficult to study owing to their localization within the gastrointestinal tract. Several studies suggest an association between food allergies and a deficiency in regulatory cells. A selective decrease in the number of TGF- $\beta$-producing $\mathrm{T}$ lymphocytes, but not other cytokine-expressing $\mathrm{T}$ cells, was reported in duodenal biopsies from children with food allergies [66]. In other work, decreased allergen-responsive $\mathrm{B}$ cells expressing TGF $\beta(\mathrm{Br} 3)$ were observed in milk allergic children [67]. The actions of TGF- $\beta$ are multifold. In murine systems, TGF- $\beta$ suppresses Th2 differentiation from naïve T cells, inhibits T-cell proliferation, and induces Foxp $3^{+}$Treg cells $[68,69]$. This latter phenomenon is mediated by mucosal $\mathrm{CD} 103^{+} \mathrm{DCs}$ that induce Foxp3 in naïve $\mathrm{T}$ cells by activating latent TGF- $\beta$ via a process enhanced by retinoic acid [70-73].

There is conflicting data in animal models on the relative contribution of TGF- $\beta$-producing Th3 cells and Foxp $3^{+}$Treg cells to oral tolerance $[74,75]$. This issue is further compounded by inconsistent reports on the actions of TGF- $\beta$ in mouse and humans. Whereas this cytokine can induce and maintain Foxp 3 expression in both mouse and human CD $4^{+} \mathrm{T}$ cells, this may not confer suppressive properties in human cells [27]. Thus, T-cell mechanisms observed in mouse models of food allergy should be interpreted with caution. The site of tolerance induction within the gut is also subject to debate. It was recently reported in a mouse model of oral tolerance that $\mathrm{CD} 4^{+} \mathrm{T}$ cells present in the organized lymphoid tissues 
of the Peyer's patches express TGF- $\beta$ RII and upregulate Foxp3 in response to oral challenge [76]. In that report, mice lacking TGF $\beta$ RII signaling failed to mount a tolerant response, indicating a requirement for Foxp $3^{+}$Treg cells induced by TGF- $\beta$. By contrast, in a mouse model of peanut anaphylaxis, IFN- $\gamma$-producing $\mathrm{CD} 8^{+} \mathrm{T}$ cells in the mesenteric lymph nodes were required for protection induced by a Chinese herbal remedy [77, 78]. Unfortunately, studying allergen-responsive human $\mathrm{CD}^{+} \mathrm{T}$ cells in vitro is problematic owing to their anatomic inaccessibility and weak proliferative capacity upon stimulation ex vivo. Consequently, the role of $\mathrm{CD} 8^{+} \mathrm{T}$ cells in promoting, or else attenuating, responses to food and inhalant allergens has largely been overlooked.

\section{New Insights into Protective Antibodies}

\section{Role of IgG4 Antibodies}

The rise in $\operatorname{IgG}$ and $\operatorname{IgG} 4$ antibodies during successful IT is well documented. IgG4 antibodies bind Fc $\gamma$ receptors with low affinity, do not fix complement and inhibit IgG1mediated complement activation. In addition, these antibodies do not precipitate antigen owing to their ability to bind different antigens at each antigen binding site [79]. This bispecific feature limits the size of antigen-antibody complexes through reduced crosslinking [80]. As a consequence, this may reduce triggering of $\mathrm{IgE}$ receptor via surface bound $\mathrm{IgE}$ on a variety of cell types. The capacity for IgG4 antibodies induced during IT to decrease IgE receptor-facilitated allergen binding to B cells has been demonstrated [81, 82]. This feature will likely also diminish activation of mast cells and basophils. The functional properties of IgG4 antibodies, as opposed to serum titers, correlate with clinical response [83]. Consistent with this, the inhibitory bioactivity of allergen-specific IgG antibodies persists for several years after discontinuation of IT, despite a decline in specific IgG1 and IgG4 antibodies to levels close to those existing prior to IT [84]. Thus, long-term clinical tolerance may be maintained, at least in part, by the persistence of a subset of allergenspecific IgG antibodies with potent inhibitory activity.

In patients receiving grass pollen IT, IgG4 antibodies account for $<40 \%$ of the inhibitory bioactivity in serum in assays dependent on IgE-grass pollen binding [84]. This phenomenon may be explained, at least in part, by the types of APCs used to test the blocking action of IgG4 antibodies (ie. B cells versus myeloid DCs). Myeloid DCs expressing the high affinity IgE receptor, FceRI, play a critical role in T-cell events occurring in vivo in atopic subjects $[85,86]$. Thus, studying how these cells interact with IgG4 antibodies could prove insightful. Alternatively, other IgG subclasses, as well as other undefined serum factors, may contribute to inhibition of allergen binding to APCs in allergen tolerance.

\section{Role of Glycosylated Antibodies}

New evidence indicates that different $\mathrm{Fc}$ N-linked glycosylation patterns determine the proversus anti-inflammatory functions of $\mathrm{IgG}$ antibodies. In groundbreaking work, it was discovered that $\mathrm{Fc}$ sialylation was pivotal to the anti-inflammatory actions of intravenous immunoglobulin (IVIG) [87]. Sialylated antibodies bind to the C-type lectin DC-SIGN present on myeloid cells [88]. These antibodies inhibit Th1-driven inflammatory processes through enhanced induction of the inhibitory Fc receptor, Fc $\gamma \mathrm{RIIB}$, on macrophages [89]. 
Surprisingly, this phenomenon is promoted by IL-33-driven expansion of IL-4-secreting basophils. Recent observations also support a role for Fc sialylation of $\mathrm{IgG}$ antibodies in allergen tolerance. Mice immunized with OVA under tolerogenic conditions have been shown to produce antigen-specific IgG antibodies that are $\mathrm{Fc}$ sialylated. In that study, sialylated, but not nonsialylated, antibodies that were generated in vitro, inhibited DC maturation in vitro and protected against allergic inflammation induced by OVA [90]. Extending these observations to humans, sialylated allergen-specific IgG antibodies have been identified in the serum of patients receiving IT for birch pollen allergy [90]. The ability for sialylated $\operatorname{IgG}$ molecules to enhance surface expression of Fc $\gamma \mathrm{RIIB}$, a receptor known to inhibit IgE receptor signaling, is intriguing [89, 91, 92]. Despite this, inhibition of DC maturation by sialylated IgG appears not to involve Fc $\gamma \mathrm{RIIB}$, suggesting that $\mathrm{Fc}$ sialylation triggers alternate regulatory pathways in allergen tolerance [90]. Such pathways likely complement the "blocking" actions of IgG antibodies.

\section{Role of Antibodies in the Gut}

Recent studies support a role for serum IgA (as well as $\operatorname{IgG}$ ) in suppressing allergic responses to food allergens. In mouse models, ingested food antigens must be absorbed to induce either anaphylaxis or diarrhea [93, 94]. While this may not be unexpected for anaphylaxis, it is perhaps less expected in the case of diarrhea. In those studies, mice with high serum IgA but low IgA levels in the gut lumen, showed slower development of allergic diarrhea, than wildtype animals [94]. Thus, while secretory IgA may act as a gatekeeper to neutralize food proteins in the gut, IgA in the serum is pivotal to limiting allergic responses. In the same animal model, IgE-mediated allergic diarrhea was suppressed by serum IgG1 (the murine equivalent of human IgG4). This process was independent of Fc $\gamma$ RIIB, which inhibits IgE-dependent activation of mast cells and basophils. Instead, the authors proposed that IgG1 antibodies (as well as IgA) intercept absorbed antigen and thus, prevent binding to mast cells. In a different mouse model of egg allergy, oral administration of T-cell epitope peptides of ovomucoid, the dominant egg-white allergen, resulted in increased production of the Th1-associated isotype, $\mathrm{IgG} 2$, as well as $\mathrm{IgA}$. By contrast, IgG1 antibodies were actually decreased [95]. This study, which also demonstrated subtle differences in immune outcomes depending on whether single or multiple peptides were used, raises the question of whether the use of oral peptides is adequate for the induction of blocking antibodies.

\section{Emerging Concepts in Regulatory Networks}

\section{T Cell Plasticity and Allergic Inflammation}

It is apparent that allergen tolerance reflects a complex regulatory system involving multiple cell types and molecules (Figure 2). The nature of immune interactions required for tolerance induction is dependent upon the constituents residing at the anatomical site of antigen encounter, the type and dose of antigen, the presence of adjuvants, and immune status of the host. In order to understand how regulatory cell types are induced, as well as their functional properties, it is important to recognize the plasticity within the immune system. If we first consider $\mathrm{CD} 4^{+} \mathrm{T}$ cells, these cells represent a vastly heterogeneous mixture. A variety of $\mathrm{CD} 4^{+} \mathrm{T}$ cell subsets, each with their own master transcription factors and cytokine profiles, have been identified. These include the helper $\mathrm{CD} 4^{+} \mathrm{T}$ cells, Th1, Th2 
and Th17, which express the transcription factors, T-bet, GATA-3 and ROR $\gamma$ respectively, and Treg cells expressing Foxp3. These subsets were originally believed to constitute distinct lineages with inflexible phenotypes. However, it is now recognized that $\mathrm{CD} 4^{+} \mathrm{T}$ cells can not only change the profile of cytokines secreted, but also alter their expression of master regulators [96]. For example, Treg cells can acquire expression of transcription factors characteristic of their effector T-cell counterparts [97, 98]. Moreover, expression of these "hijacked" factors appears to be required for optimal Treg cell-mediated suppression.

Recent work highlights the flexibility of Th2 cells. In vitro differentiated IL-4-producing Th2 cells specific for lymphocytic choriomeningitis virus (LCMV) were shown to acquire the ability to produce IFN- $\gamma$ upon transfer into mice that were subsequently infected with LCMV [99]. In addition to the capacity to broaden their cytokine repertoire, there is evidence that Th2 effector cells can convert to Foxp $3^{+}$Treg cells and that this pathway is bidirectional. In mice, treatment of antigen-specific memory Th 2 cells by TGF- $\beta$ in the presence of all-trans retinoic acid and rapamycin resulted in expression of Foxp3 and downregulation of the Th2-associated transcription factors GATA-3 and IRF-4, in conjunction with decreased Th2 cytokine production [100]. These cells suppressed Th2mediated airway hyperreactivity, eosinophilia, and specific IgE antibody production, in a mouse model of asthma. Conversely, in humans, memory Treg cells downregulate Foxp3 expression upon in vitro expansion [101, 102]. This change is accompanied by upregulation of Th2 signature genes, and occurs under non-polarizing conditions, suggesting that Th2 differentiation is the default developmental program in human Treg cells that downregulate Foxp3 [103]. There is evidence to suggest that T-cells with an intermediate phenotype between human Th2 and Treg cells exist in allergic disease. Work by our group showed that sort-purified $\mathrm{CD} 25^{\text {hi }} \mathrm{CD} 4^{+} \mathrm{T}$ cells isolated from the blood of highly atopic patients were almost exclusively Foxp $3^{+}$, but nonetheless had the capacity to secrete Th2 cytokines [28]. When considered collectively, these observations highlight the influence of both intrinsic and extrinsic signals on T cell phenotype and function. Thus, as our understanding of T-cell differentiation continues to evolve, it will be necessary to re-frame our concept of discrete subsets, based on the shared features of many $\mathrm{T}$ cell types that were previously thought to exist as discrete terminally differentiated lineages. With this in mind, a simple model of allergen tolerance, wherein Treg cells act to suppress Th2 cells seems unlikely. Instead, "Th2 suppression" likely reflects a highly dynamic process involving not only de novo induction of Treg cells, but also conversion of Th2 effectors to Treg cells and to T effector cells with altered cytokine profiles.

\section{Relevance of Allergen Encounter at Anatomical Sites}

Since external cues are required for T-cell differentiating events to occur, certain anatomical sites of antigen exposure may be more effective at inducing Treg cells during the development of allergen tolerance. Sublingual immunotherapy (SLIT) is gaining favor as a safe and effective alternative treatment to subcutaneous IT for the treatment of allergic rhinitis [104, 105]. Changes in a variety of immune parameters, including rise in serum IgA and $\operatorname{IgG} 4$, along with an increase in Foxp $3^{+}$cells in the sublingual epithelium, indicate that this strategy favors the induction of allergen tolerance [106, 107]. Administering allergen through the oral cavity, as opposed to through the skin, may not only prove safer from a 
clinical standpoint, but also offer the advantage of enhanced induction of regulatory cells. Consistent with this view, T cells within the oral mucosa express higher levels of TGF- $\beta 1$ and IL-10 than those in the skin [108]. Moreover, allergen binding to oral mucosal Langerhans cells appears to increase the production of tolerogenic cytokines [108]. By contrast, the skin of allergic subjects is an important source of cytokines that promote Th2driven inflammation. As such, allergen administered subcutaneously may encounter dermal DCs that are equipped to enhance Th2 responses, as appears to be the case for patients with atopic dermatitis (AD). Keratinocytes present in the skin lesions of these patients express increased levels of the Th2-promoting cytokine, TSLP [7]. In addition, blood DCs from subjects with AD have the capacity to efficiently upregulate TSLP receptor in response to allergen priming [86]. This phenomenon potentiates the TSLP pathway in DCs resulting in a synergistic enhancement of Th2 responses in vitro by DCs that have been co-primed with allergen and TSLP. Such a phenomenon could explain why some patients with AD who receive conventional IT via the subcutaneous route experience exacerbation of their skin disease.

\section{Dual Functionality and Immune Regulation}

Not only is the in vivo milieu relevant to Treg cell induction, but Treg cells themselves may also modulate their own microenvironment. In mice, CD25+ Treg cells can suppress mast cell degranulation through a cell contact-dependent pathway involving OX40-OX40L interactions, and in vivo depletion of these cells enhances the anaphylactic response [16]. On the other hand, Treg cells can augment production of IL-6 by mast cells through surfacebound TGF- $\beta$ [109]. The amount of mast cell-derived IL-6 produced is sufficient to promote differentiation of naïve $\mathrm{CD} 4^{+} \mathrm{T}$ cells to Th17 cells in the presence of TGF- $\beta$. Adoptive transfer of Treg cells confirmed their contrasting effects on mast cells in a mouse model of food allergy [109]. The notion of dual functionality extends beyond Treg cells to other cell types involved in allergic disease, including mast cells which were recently shown to support Treg cell-mediated suppression of chronic allergic skin inflammation [110]. This phenomenon is perhaps not surprising given the capacity for mast cells (and basophils) to exert pro- or anti-inflammatory effects depending on the nature of the disease, and their ability to vary their output of mediators depending upon the activation signal provided [111, 112]. Such multiplicity of labor may not only serve to modify the inflammatory milieu, but also regulate chronic inflammatory processes, thereby limiting collateral damage.

Similar immune cell type may fulfill different roles depending, not only on the stage of the inflammatory process, but also on anatomic localization. For example, while mucosal $\mathrm{CD} 103^{+}$DCs may be critical to tolerance induction in the gut, recent evidence in mice supports a key role for pulmonary $\mathrm{CD}_{103^{+}} \mathrm{DCs}$ in priming $\mathrm{Th} 2$ responses to inhalant allergen [113]. Th2 priming by $\mathrm{CD} 103^{+}$DCs appears to depend on low level antigen uptake occurring in vivo, since the same cells forced to present high dose antigen ex vivo preferentially primed Th1 and Th17 differentiation. In the same study, the ability for lung $\mathrm{CD} 103^{+}$DCs, but not CD11 $\mathrm{b}^{\text {hi }}$ DCs, to prime Th2 responses after allergen exposure in vivo, implied a requirement for signals unique to $\mathrm{CD} 103^{+} \mathrm{DCs}$. Designing allergens to alter the mode of allergen delivery to DCs by targeting alternate surface receptors, could prove a useful strategy to "switch off" these signals in order to attain tolerance. 


\section{Future Directions}

The development of allergen tolerance reflects regulatory networks that involve multiple secreted mediators, surface molecules and regulatory cell types. Allergic diseases are highly heterogeneous, both in their clinical phenotype, and in their immunopathogenic origins. A role for a broad array of pathogenic cells is now apparent in asthma. In accordance with this, novel cell types continue to emerge that could provide a target for regulatory cell types. Examples of these include innate cells which respond to epithelial-derived cytokines and have the capacity to secrete Th2 cytokines [114, 115]. Future research directions should include elucidating the properties of novel effector cells, as well as the suppressor effects of "non-conventional" regulatory cells, including B cells and mast cells. Exploring T-cell plasticity in the context of allergic disease in humans is also essential if we are to fully understand mechanisms of allergen tolerance. In particular, understanding how T-cell trafficking can be re-programmed in vivo would aid in the design of delivery systems for tolerogenic molecules.

The research tools available for studying allergen tolerance continue to evolve at a rapid pace. In this new era of human proteomics and genomics, the possibilities seem countless, yet daunting at the same time; however, creative approaches are already yielding fruit. In a recent study which used two complementary proteomic strategies to analyze human regulatory DCs, novel candidate biomarkers of clinical responsiveness to allergen IT were identified [116]. Adopting a systems biology approach for studying the development of tolerance in humans could avoid the pitfalls of previous clinical trials of IT that were not optimally designed to capture markers of allergen tolerance.

It is now well recognized that intestinal microbiota influence the human immune system through the induction of both Treg cells and effector cells. Recent work suggests a link between the development of allergic disease and reduced diversity of gut microbiota [117]. Certain bacterial species within the gut may favor the induction of Treg cells [118], and the presence or absence of these species appear to be linked to both allergy, and microbial diversity within the environment [119]. Proteogenomic approaches offer much promise for studying these interactions, and for delineating protective from non-protective bacterial species in the commensal microbiota.

New strategies to induce allergen tolerance are in the pipeline, which incorporate novel allergen formulations and modes of delivery. Sublingual IT offers promise for safe and effective tolerance induction to a variety of inhalant allergens. Treatment of food allergy should also be a high priority, given the continued rise in prevalence of sensitization to foods. While oral IT appears to be clinically efficacious, alternate approaches are warranted that could curtail the length of time taken to attain tolerance. This could involve the use of liposome-encased allergen formulations that induce different $T$ regulatory cell types [120]. Though the challenges to inducing allergen tolerance are many, the significant strides made in recent years will pave the way for new therapies capable of providing long lasting benefit to allergic patients. 


\section{Acknowledgments}

This work is supported by NIH grants R01 AR059058 (J.W.) and R01 AI052196 (J.W.).

\section{List of abbreviations}
AD atopic dermatitis
DC dendritic cell
IT immunotherapy
PLA2 Phospholipase $\mathrm{A}_{2}$
Treg T regulatory

\section{References}

1. Billingham RE, Brent L, Medawar PB. Actively acquired tolerance of foreign cells. Nature. 1953; 172:603-6. [PubMed: 13099277]

2. Varshney P, Steele PH, Vickery BP, Bird JA, Thyagarajan A, Scurlock AM, Perry TT, Jones SM, Burks AW. Adverse reactions during peanut oral immunotherapy home dosing. J Allergy Clin Immunol. 2009; 124:1351-2. [PubMed: 19913285]

3. Vickery BP, Burks W. Oral immunotherapy for food allergy. Curr Opin Pediatr. 2010; 22:765-70. [PubMed: 20852423]

4. Platts-Mills T, Vaughan J, Squillace S, Woodfolk J, Sporik R. Sensitisation asthma, and a modified Th2 response in children exposed to cat allergen: a population-based cross-sectional study. Lancet. 2001; 357:752-6. [PubMed: 11253969]

5. Eisenbarth SC, Piggott DA, Huleatt JW, Visintin I, Herrick CA, Bottomly K. Lipopolysaccharideenhanced, toll-like receptor 4-dependent $\mathrm{T}$ helper cell type 2 responses to inhaled antigen. $\mathrm{J}$ Exp Med. 2002; 196:1645-51. [PubMed: 12486107]

6. Trompette A, Divanovic S, Visintin A, Blanchard C, Hegde RS, Madan R, Thorne PS, Wills-Karp M, Gioannini TL, Weiss JP, Karp CL. Allergenicity resulting from functional mimicry of a Toll-like receptor complex protein. Nature. 2009; 457:585-8. [PubMed: 19060881]

7. Soumelis V, Reche PA, Kanzler H, Yuan W, Edward G, Homey B, Gilliet M, Ho S, Antonenko S, Lauerma A, Smith K, Gorman D, Zurawski S, Abrams J, Menon S, McClanahan T, de WaalMalefyt Rd R, Bazan F, Kastelein RA, Liu YJ. Human epithelial cells trigger dendritic cell mediated allergic inflammation by producing TSLP. Nat Immunol. 2002; 3:673-80. [PubMed: 12055625]

8. Ito T, Wang YH, Duramad O, Hori T, Delespesse GJ, Watanabe N, Qin FX, Yao Z, Cao W, Liu YJ. TSLP-activated dendritic cells induce an inflammatory T helper type 2 cell response through OX40 ligand. J Exp Med. 2005; 202:1213-23. [PubMed: 16275760]

9. Zhou B, Comeau MR, De Smedt T, Liggitt HD, Dahl ME, Lewis DB, Gyarmati D, Aye T, Campbell DJ, Ziegler SF. Thymic stromal lymphopoietin as a key initiator of allergic airway inflammation in mice. Nat Immunol. 2005; 6:1047-53. [PubMed: 16142237]

10. Allakhverdi Z, Comeau MR, Jessup HK, Yoon BR, Brewer A, Chartier S, Paquette N, Ziegler SF, Sarfati M, Delespesse G. Thymic stromal lymphopoietin is released by human epithelial cells in response to microbes, trauma or inflammation and potently activates mast cells. J Exp Med. 2007; 204:253-8. [PubMed: 17242164]

11. Hurst SD, Muchamuel T, Gorman DM, Gilbert JM, Clifford T, Kwan S, Menon S, Seymour B, Jackson C, Kung TT, Brieland JK, Zurawski SM, Chapman RW, Zurawski G, Coffman RL. New IL-17 family members promote Th1 or Th2 responses in the lung: in vivo function of the novel cytokine IL-25. J Immunol. 2002; 169:443-53. [PubMed: 12077275]

12. Schmitz J, Owyang A, Oldham E, Song Y, Murphy E, McClanahan TK, Zurawski G, Moshrefi M, Qin J, Li X, Gorman DM, Bazan JF, Kastelein RA. IL-33, an interleukin-1-like cytokine that 
signals via the IL-1 receptor-related protein ST2 and induces T helper type 2-associated cytokines. Immunity. 2005; 23:479-90. [PubMed: 16286016]

13. Bellinghausen I, Brand U, Steinbrink K, Enk AH, Knop J, Saloga J. Inhibition of human allergic Tcell responses by IL-10-treated dendritic cells: differences from hydrocortisone-treated dendritic cells. J Allergy Clin Immunol. 2001; 108:242-9. [PubMed: 11496241]

14. Koya T, Matsuda H, Takeda K, Matsubara S, Miyahara N, Balhorn A, Dakhama A, Gelfand EW. IL-10-treated dendritic cells decrease airway hyperresponsiveness and airway inflammation in mice. J Allergy Clin Immunol. 2007; 119:1241-50. [PubMed: 17353041]

15. Li X, Yang A, Huang H, Zhang X, Town J, Davis B, Cockcroft DW, Gordon JR. Induction of type $2 \mathrm{~T}$ helper cell allergen tolerance by IL-10-differentiated regulatory dendritic cells. Am J Respir Cell Mol Biol. 2010; 42:190-9. [PubMed: 19372244]

16. Gri G, Piconese S, Frossi B, Manfroi V, Merluzzi S, Tripodo C, Viola A, Odom S, Rivera J, Colombo MP, Pucillo CE. CD4+CD25+ regulatory T cells suppress mast cell degranulation and allergic responses through OX40-OX40L interaction. Immunity. 2008; 29:771-81. [PubMed: 18993084]

17. Jeannin P, Lecoanet S, Delneste Y, Gauchat JF, Bonnefoy JY. IgE versus IgG4 production can be differentially regulated by IL-10. J Immunol. 1998; 160:3555-61. [PubMed: 9531318]

18. Satoguina JS, Adjobimey T, Arndts K, Hoch J, Oldenburg J, Layland LE, Hoerauf A. Tr1 and naturally occurring regulatory $\mathrm{T}$ cells induce $\mathrm{IgG} 4$ in B cells through GITR/GITR-L interaction, IL-10 and TGF-beta. Eur J Immunol. 2008; 38:3101-13. [PubMed: 18924213]

19. Shevach EM. Mechanisms of foxp3+ T regulatory cell-mediated suppression. Immunity. 2009; 30:636-45. [PubMed: 19464986]

20. Hsieh CS, Lee HM, Lio CW. Selection of regulatory T cells in the thymus. Nat Rev Immunol. 2012; 12:157-67. [PubMed: 22322317]

21. Cobbold SP, Castejon R, Adams E, Zelenika D, Graca L, Humm S, Waldmann H. Induction of foxP3+ regulatory $\mathrm{T}$ cells in the periphery of $\mathrm{T}$ cell receptor transgenic mice tolerized to transplants. J Immunol. 2004; 172:6003-10. [PubMed: 15128783]

22. Kretschmer K, Apostolou I, Hawiger D, Khazaie K, Nussenzweig MC, von Boehmer H. Inducing and expanding regulatory $T$ cell populations by foreign antigen. Nat Immunol. 2005; 6:1219-27. [PubMed: 16244650]

23. Haribhai D, Williams JB, Jia S, Nickerson D, Schmitt EG, Edwards B, Ziegelbauer J, Yassai M, Li SH, Relland LM, Wise PM, Chen A, Zheng YQ, Simpson PM, Gorski J, Salzman NH, Hessner MJ, Chatila TA, Williams CB. A requisite role for induced regulatory T cells in tolerance based on expanding antigen receptor diversity. Immunity. 2011; 35:109-22. [PubMed: 21723159]

24. Kendal AR, Chen Y, Regateiro FS, Ma J, Adams E, Cobbold SP, Hori S, Waldmann H. Sustained suppression by Foxp3+ regulatory T cells is vital for infectious transplantation tolerance. J Exp Med. 2011; 208:2043-53. [PubMed: 21875958]

25. Curotto de Lafaille MA, Kutchukhidze N, Shen S, Ding Y, Yee H, Lafaille JJ. Adaptive Foxp3+ regulatory T cell-dependent and -independent control of allergic inflammation. Immunity. 2008; 29:114-26. [PubMed: 18617425]

26. Voo KS, Wang YH, Santori FR, Boggiano C, Arima K, Bover L, Hanabuchi S, Khalili J, Marinova E, Zheng B, Littman DR, Liu YJ. Identification of IL-17-producing FOXP3+ regulatory T cells in humans. Proc Natl Acad Sci U S A. 2009; 106:4793-8. [PubMed: 19273860]

27. Zheng SG, Gray JD, Ohtsuka K, Yamagiwa S, Horwitz DA. Generation ex vivo of TGF-betaproducing regulatory T cells from CD4+CD25- precursors. J Immunol. 2002; 169:4183-9. [PubMed: 12370347]

28. Rao PE, Petrone AL, Ponath PD. Differentiation and expansion of T cells with regulatory function from human peripheral lymphocytes by stimulation in the presence of TGF-beta. J Immunol. 2005; 174:1446-55. [PubMed: 15661903]

29. Lu L, Zhou X, Wang J, Zheng SG, Horwitz DA. Characterization of protective human CD4CD25 FOXP3 regulatory T cells generated with IL-2, TGF-beta and retinoic acid. PLoS One. 2010; 5:e15150. [PubMed: 21179414] 
30. Allan SE, Crome SQ, Crellin NK, Passerini L, Steiner TS, Bacchetta R, Roncarolo MG, Levings MK. Activation-induced FOXP3 in human T effector cells does not suppress proliferation or cytokine production. Int Immunol. 2007; 19:345-54. [PubMed: 17329235]

31. Gavin MA, Torgerson TR, Houston E, DeRoos P, Ho WY, Stray-Pedersen A, Ocheltree EL, Greenberg PD, Ochs HD, Rudensky AY. Single-cell analysis of normal and FOXP3-mutant human T cells: FOXP3 expression without regulatory T cell development. Proc Natl Acad Sci U S A. 2006; 103:6659-64. [PubMed: 16617117]

32. Tran DQ, Ramsey H, Shevach EM. Induction of FOXP3 expression in naive human CD4+FOXP3 $\mathrm{T}$ cells by $\mathrm{T}$-cell receptor stimulation is transforming growth factor-beta dependent but does not confer a regulatory phenotype. Blood. 2007; 110:2983-90. [PubMed: 17644734]

33. Reefer AJ, Satinover SM, Solga MD, Lannigan JA, Nguyen JT, Wilson BB, Woodfolk JA. Analysis of CD25hiCD4+ "regulatory" T-cell subtypes in atopic dermatitis reveals a novel TH2like population. J Allergy Clin Immunol. 2008; 121:415-22. e3. [PubMed: 18177697]

34. Floess S, Freyer J, Siewert C, Baron U, Olek S, Polansky J, Schlawe K, Chang HD, Bopp T, Schmitt E, Klein-Hessling S, Serfling E, Hamann A, Huehn J. Epigenetic control of the foxp3 locus in regulatory T cells. PLoS Biol. 2007; 5:e38. [PubMed: 17298177]

35. Baron U, Floess S, Wieczorek G, Baumann K, Grutzkau A, Dong J, Thiel A, Boeld TJ, Hoffmann P, Edinger M, Turbachova I, Hamann A, Olek S, Huehn J. DNA demethylation in the human FOXP3 locus discriminates regulatory T cells from activated FOXP3+ conventional T cells. Eur J Immunol. 2007; 37:2378-89. [PubMed: 17694575]

36. Lal G, Zhang N, van der Touw W, Ding Y, Ju W, Bottinger EP, Reid SP, Levy DE, Bromberg JS. Epigenetic regulation of Foxp3 expression in regulatory T cells by DNA methylation. J Immunol. 2009; 182:259-73. [PubMed: 19109157]

37. Francis JN, James LK, Paraskevopoulos G, Wong C, Calderon MA, Durham SR, Till SJ. Grass pollen immunotherapy: IL-10 induction and suppression of late responses precedes IgG4 inhibitory antibody activity. J Allergy Clin Immunol. 2008; 121:1120-25. e2. [PubMed: 18374405]

38. Akdis CA, Blesken T, Akdis M, Wuthrich B, Blaser K. Role of interleukin 10 in specific immunotherapy. J Clin Invest. 1998; 102:98-106. [PubMed: 9649562]

39. Meiler F, Zumkehr J, Klunker S, Ruckert B, Akdis CA, Akdis M. In vivo switch to IL-10-secreting T regulatory cells in high dose allergen exposure. J Exp Med. 2008; 205:2887-98. [PubMed: 19001136]

40. Tsai YG, Chien JW, Chen WL, Shieh JJ, Lin CY. Induced apoptosis of TH2 lymphocytes in asthmatic children treated with Dermatophagoides pteronyssinus immunotherapy. Pediatr Allergy Immunol. 2005; 16:602-8. [PubMed: 16238586]

41. Wambre E, DeLong JH, James EA, LaFond RE, Robinson D, Kwok WW. Differentiation stage determines pathologic and protective allergen-specific CD4+ T-cell outcomes during specific immunotherapy. J Allergy Clin Immunol. 2011; 129:544-51. 51 e1-7. [PubMed: 21975176]

42. Wills-Karp M. Allergen-specific pattern recognition receptor pathways. Curr Opin Immunol. 2010; 22:777-82. [PubMed: 21093238]

43. Emara M, Royer PJ, Abbas Z, Sewell HF, Mohamed GG, Singh S, Peel S, Fox J, Shakib F, Martinez-Pomares L, Ghaemmaghami AM. Recognition of the major cat allergen Fel d 1 through the cysteine-rich domain of the mannose receptor determines its allergenicity. J Biol Chem. 2011; 286:13033-40. [PubMed: 21335554]

44. Royer PJ, Emara M, Yang C, Al-Ghouleh A, Tighe P, Jones N, Sewell HF, Shakib F, MartinezPomares L, Ghaemmaghami AM. The mannose receptor mediates the uptake of diverse native allergens by dendritic cells and determines allergen-induced $\mathrm{T}$ cell polarization through modulation of IDO activity. J Immunol. 2010; 185:1522-31. [PubMed: 20610655]

45. Kouzaki H, O'Grady SM, Lawrence CB, Kita H. Proteases induce production of thymic stromal lymphopoietin by airway epithelial cells through protease-activated receptor-2. J Immunol. 2009; 183:1427-34. [PubMed: 19561109]

46. Asokananthan N, Graham PT, Stewart DJ, Bakker AJ, Eidne KA, Thompson PJ, Stewart GA. House dust mite allergens induce proinflammatory cytokines from respiratory epithelial cells: the 
cysteine protease allergen, Der p 1, activates protease-activated receptor (PAR)-2 and inactivates PAR-1. J Immunol. 2002; 169:4572-8. [PubMed: 12370395]

47. Arizmendi NG, Abel M, Mihara K, Davidson C, Polley D, Nadeem A, El Mays T, Gilmore BF, Walker B, Gordon JR, Hollenberg MD, Vliagoftis H. Mucosal allergic sensitization to cockroach allergens is dependent on proteinase activity and proteinase-activated receptor-2 activation. $\mathrm{J}$ Immunol. 2011; 186:3164-72. [PubMed: 21270400]

48. Kaiser L, Gronlund H, Sandalova T, Ljunggren HG, van Hage-Hamsten M, Achour A, Schneider G. The crystal structure of the major cat allergen Fel d 1, a member of the secretoglobin family. $\mathrm{J}$ Biol Chem. 2003; 278:37730-5. [PubMed: 12851385]

49. Kaiser L, Velickovic TC, Badia-Martinez D, Adedoyin J, Thunberg S, Hallen D, Berndt K, Gronlund H, Gafvelin G, van Hage M, Achour A. Structural characterization of the tetrameric form of the major cat allergen Fel d 1. J Mol Biol. 2007; 370:714-27. [PubMed: 17543334]

50. Johansson S, Andersson K, Wennergren G, Wenneras C, Rudin A. CC16 inhibits the migration of eosinophils towards the formyl peptide fMLF but not towards PGD2. Inflammation. 2009; 32:659. [PubMed: 19132521]

51. Yoon JM, Lee KH, Lee SM, Lim JJ, Yang SC, Yoo CG, Lee CT, Han SK, Shim YS, Kim YW. The immune modulation of Clara cell-10 in human peripheral monocytes and dendritic cells. Int J Mol Med. 2010; 26:415-23. [PubMed: 20664959]

52. Ray R, Zhang Z, Lee YC, Gao JL, Mukherjee AB. Uteroglobin suppresses allergen-induced TH2 differentiation by down-regulating the expression of serum amyloid A. SOCS-3 genes. FEBS Lett. 2006; 580:6022-6. [PubMed: 17046755]

53. Lensmar C, Nord M, Gudmundsson GH, Roquet A, Andersson O, Jornvall H, Eklund A, Grunewald J, Agerberth B. Decreased pulmonary levels of the anti-inflammatory Clara cell 16 $\mathrm{kDa}$ protein after induction of airway inflammation in asthmatics. Cell Mol Life Sci. 2000; 57:976-81. [PubMed: 10950311]

54. Reefer AJ, Carneiro RM, Custis NJ, Platts-Mills TA, Sung SS, Hammer J, Woodfolk JA. A role for IL-10-mediated HLA-DR7-restricted T cell-dependent events in development of the modified Th2 response to cat allergen. J Immunol. 2004; 172:2763-72. [PubMed: 14978075]

55. Worm M, Lee HH, Kleine-Tebbe J, Hafner RP, Laidler P, Healey D, Buhot C, Verhoef A, Maillere B, Kay AB, Larche M. Development and preliminary clinical evaluation of a peptide immunotherapy vaccine for cat allergy. J Allergy Clin Immunol. 2011; 127:89-97. 97 e1-14. [PubMed: 21211644]

56. Bateman EA, Ardern-Jones MR, Ogg GS. Identification of an immunodominant region of Fel d 1 and characterization of constituent epitopes. Clin Exp Allergy. 2008; 38:1760-8. [PubMed: 19489916]

57. Alexander C, Tarzi M, Larche M, Kay AB. The effect of Fel d 1-derived T-cell peptides on upper and lower airway outcome measurements in cat-allergic subjects. Allergy. 2005; 60:1269-74. [PubMed: 16134993]

58. Campbell JD, Buckland KF, McMillan SJ, Kearley J, Oldfield WL, Stern LJ, Gronlund H, van Hage M, Reynolds CJ, Boyton RJ, Cobbold SP, Kay AB, Altmann DM, Lloyd CM, Larche M. Peptide immunotherapy in allergic asthma generates IL-10-dependent immunological tolerance associated with linked epitope suppression. J Exp Med. 2009; 206:1535-47. [PubMed: 19528258]

59. Yanaba K, Bouaziz JD, Haas KM, Poe JC, Fujimoto M, Tedder TF. A regulatory B cell subset with a unique CD1dhiCD5+ phenotype controls T cell-dependent inflammatory responses. Immunity. 2008; 28:639-50. [PubMed: 18482568]

60. Haas KM, Watanabe R, Matsushita T, Nakashima H, Ishiura N, Okochi H, Fujimoto M, Tedder TF. Protective and pathogenic roles for B cells during systemic autoimmunity in NZB/W F1 mice. J Immunol. 2010; 184:4789-800. [PubMed: 20368280]

61. Yanaba K, Bouaziz JD, Matsushita T, Tsubata T, Tedder TF. The development and function of regulatory B cells expressing IL-10 (B10 cells) requires antigen receptor diversity and TLR signals. J Immunol. 2009; 182:7459-72. [PubMed: 19494269]

62. Amu S, Saunders SP, Kronenberg M, Mangan NE, Atzberger A, Fallon PG. Regulatory B cells prevent and reverse allergic airway inflammation via FoxP3-positive $\mathrm{T}$ regulatory cells in a murine model. J Allergy Clin Immunol. 2010; 125:1114-24 e8. [PubMed: 20304473] 
63. Iwata Y, Matsushita T, Horikawa M, Dilillo DJ, Yanaba K, Venturi GM, Szabolcs PM, Bernstein SH, Magro CM, Williams AD, Hall RP, St Clair EW, Tedder TF. Characterization of a rare IL-10competent B-cell subset in humans that parallels mouse regulatory B10 cells. Blood. 2011; 117:530-41. [PubMed: 20962324]

64. Noh J, Noh G, Kim HS, Kim AR, Choi WS. Allergen-specific responses of CD19+CD5+Foxp3+ regulatory B cells (Bregs) and CD4+Foxp3+ regulatory $\mathrm{T}$ cell (Tregs) in immune tolerance of cow milk allergy of late eczematous reactions. Cell Immunol. 2012; 274:109-14. [PubMed: 22398308]

65. Noh J, Noh G, Lee SJ, Lee JH, Kim A, Kim HS, Choi WS. Tolerogenic effects of interferongamma with induction of allergen-specific interleukin-10-producing regulatory B cell $(\mathrm{Br} 1)$ changes in non-IgE-mediated food allergy. Cell Immunol. 2012; 273:140-9. [PubMed: 22336594]

66. Perez-Machado MA, Ashwood P, Thomson MA, Latcham F, Sim R, Walker-Smith JA, Murch SH. Reduced transforming growth factor-beta1-producing $\mathrm{T}$ cells in the duodenal mucosa of children with food allergy. Eur J Immunol. 2003; 33:2307-15. [PubMed: 12884306]

67. Lee JH, Noh J, Noh G, Choi WS, Cho S, Lee SS. Allergen-specific transforming growth factorbeta-producing $\mathrm{CD} 19+\mathrm{CD} 5+$ regulatory $\mathrm{B}$-cell $(\mathrm{Br} 3)$ responses in human late eczematous allergic reactions to cow's milk. J Interferon Cytokine Res. 2011; 31:441-9. [PubMed: 21291325]

68. McKarns SC, Schwartz RH, Kaminski NE. Smad3 is essential for TGF-beta 1 to suppress IL-2 production and TCR-induced proliferation, but not IL-2-induced proliferation. J Immunol. 2004; 172:4275-84. [PubMed: 15034041]

69. Heath VL, Murphy EE, Crain C, Tomlinson MG, O’Garra A. TGF-beta1 down-regulates Th2 development and results in decreased IL-4-induced STAT6 activation and GATA-3 expression. Eur J Immunol. 2000; 30:2639-49. [PubMed: 11009098]

70. Chen W, Jin W, Hardegen N, Lei KJ, Li L, Marinos N, McGrady G, Wahl SM. Conversion of peripheral CD4+CD25- naive T cells to CD4+CD25+ regulatory T cells by TGF-beta induction of transcription factor Foxp3. J Exp Med. 2003; 198:1875-86. [PubMed: 14676299]

71. Sun CM, Hall JA, Blank RB, Bouladoux N, Oukka M, Mora JR, Belkaid Y. Small intestine lamina propria dendritic cells promote de novo generation of Foxp3 T reg cells via retinoic acid. J Exp Med. 2007; 204:1775-85. [PubMed: 17620362]

72. Mucida D, Park Y, Kim G, Turovskaya O, Scott I, Kronenberg M, Cheroutre H. Reciprocal TH17 and regulatory $\mathrm{T}$ cell differentiation mediated by retinoic acid. Science. 2007; 317:256-60. [PubMed: 17569825]

73. Coombes JL, Siddiqui KR, Arancibia-Carcamo CV, Hall J, Sun CM, Belkaid Y, Powrie F. A functionally specialized population of mucosal CD103+ DCs induces Foxp3+ regulatory T cells via a TGF-beta and retinoic acid-dependent mechanism. J Exp Med. 2007; 204:1757-64. [PubMed: 17620361]

74. Ganeshan K, Neilsen CV, Hadsaitong A, Schleimer RP, Luo X, Bryce PJ. Impairing oral tolerance promotes allergy and anaphylaxis: a new murine food allergy model. J Allergy Clin Immunol. 2009; 123:231-38. e4. [PubMed: 19022495]

75. Marcondes Rezende M, Hassing I, Bol-Schoenmakers M, Bleumink R, Boon L, van Bilsen J, Pieters R. CD4+CD25+ T regulatory cells do not transfer oral tolerance to peanut allergens in a mouse model of peanut allergy. Clin Exp Allergy. 2011; 41:1324-33. [PubMed: 21338425]

76. Gilbert RS, Kobayashi R, Sekine S, Fujihashi K. Functional transforming growth factor-beta receptor type II expression by CD4+ T cells in Peyer's patches is essential for oral tolerance induction. PLoS One. 2011; 6:e27501. [PubMed: 22087328]

77. Qu C, Srivastava K, Ko J, Zhang TF, Sampson HA, Li XM. Induction of tolerance after establishment of peanut allergy by the food allergy herbal formula-2 is associated with upregulation of interferon-gamma. Clin Exp Allergy. 2007; 37:846-55. [PubMed: 17517098]

78. Srivastava KD, Qu C, Zhang T, Goldfarb J, Sampson HA, Li XM. Food Allergy Herbal Formula-2 silences peanut-induced anaphylaxis for a prolonged posttreatment period via IFN-gammaproducing CD8+ T cells. J Allergy Clin Immunol. 2009; 123:443-51. [PubMed: 19203662]

79. van der Neut Kolfschoten M, Schuurman J, Losen M, Bleeker WK, Martinez-Martinez P, Vermeulen E, den Bleker TH, Wiegman L, Vink T, Aarden LA, De Baets MH, van de Winkel JG, Aalberse RC, Parren PW. Anti-inflammatory activity of human IgG4 antibodies by dynamic Fab arm exchange. Science. 2007; 317:1554-7. [PubMed: 17872445] 
80. Aalberse R. The role of IgG antibodies in allergy and immunotherapy. Allergy. 66(Suppl 95):2830. [PubMed: 21668848]

81. Wachholz PA, Soni NK, Till SJ, Durham SR. Inhibition of allergen-IgE binding to B cells by IgG antibodies after grass pollen immunotherapy. J Allergy Clin Immunol. 2003; 112:915-22. [PubMed: 14610480]

82. Shamji MH, Durham SR. Mechanisms of immunotherapy to aeroallergens. Clin Exp Allergy. 2011; 41:1235-46. [PubMed: 21762223]

83. Shamji MH, Ljorring C, Francis JN, Calderon MA, Larche M, Kimber I, Frew AJ, Ipsen H, Lund K, Wurtzen PA, Durham SR. Functional rather than immunoreactive levels of IgG4 correlate closely with clinical response to grass pollen immunotherapy. Allergy. 2012; 67:217-26. [PubMed: 22077562]

84. James LK, Shamji MH, Walker SM, Wilson DR, Wachholz PA, Francis JN, Jacobson MR, Kimber I, Till SJ, Durham SR. Long-term tolerance after allergen immunotherapy is accompanied by selective persistence of blocking antibodies. J Allergy Clin Immunol. 2011; 127:509-16. e1-5. [PubMed: 21281875]

85. Wang YH, Ito T, Homey B, Watanabe N, Martin R, Barnes CJ, McIntyre BW, Gilliet M, Kumar R, Yao Z, Liu YJ. Maintenance and polarization of human TH2 central memory T cells by thymic stromal lymphopoietin-activated dendritic cells. Immunity. 2006; 24:827-38. [PubMed: 16782037]

86. Hulse KE, Reefer AJ, Engelhard VH, Patrie JT, Ziegler SF, Chapman MD, Woodfolk JA. Targeting allergen to FcgammaRI reveals a novel $\mathrm{T}(\mathrm{H}) 2$ regulatory pathway linked to thymic stromal lymphopoietin receptor. J Allergy Clin Immunol. 2010; 125:247-56. e1-8. [PubMed: 20109752]

87. Kaneko Y, Nimmerjahn F, Ravetch JV. Anti-inflammatory activity of immunoglobulin G resulting from Fc sialylation. Science. 2006; 313:670-3. [PubMed: 16888140]

88. Anthony RM, Wermeling F, Karlsson MC, Ravetch JV. Identification of a receptor required for the anti-inflammatory activity of IVIG. Proc Natl Acad Sci U S A. 2008; 105:19571-8. [PubMed: 19036920]

89. Anthony RM, Kobayashi T, Wermeling F, Ravetch JV. Intravenous gammaglobulin suppresses inflammation through a novel TH2 pathway. Nature. 2011; 475:110-3. [PubMed: 21685887]

90. Oefner CM, Winkler A, Hess C, Lorenz AK, Holecska V, Huxdorf M, Schommartz T, Petzold D, Bitterling J, Schoen AL, Stoehr AD, Van DV, Darcan-Nikolaisen Y, Blanchard V, Schmudde I, Laumonnier Y, Strover HA, Hegazy AN, Eiglmeier S, Schoen CT, Mertes MM, Loddenkemper C, Lohning M, Konig P, Petersen A, Luger EO, Collin M, Kohl J, Hutloff A, Hamelmann E, Berger M, Wardemann H, Ehlers M. Tolerance induction with T cell-dependent protein antigens induces regulatory sialylated IgGs. J Allergy Clin Immunol. 2012 Epub ahead of print.

91. Zhu D, Kepley CL, Zhang M, Zhang K, Saxon A. A novel human immunoglobulin Fc gamma Fc epsilon bifunctional fusion protein inhibits Fc epsilon RI-mediated degranulation. Nat Med. 2002; 8:518-21. [PubMed: 11984598]

92. Kepley CL, Taghavi S, Mackay G, Zhu D, Morel PA, Zhang K, Ryan JJ, Satin LS, Zhang M, Pandolfi PP, Saxon A. Co-aggregation of FcgammaRII with FcepsilonRI on human mast cells inhibits antigen-induced secretion and involves SHIP-Grb2-Dok complexes. J Biol Chem. 2004; 279:35139-49. [PubMed: 15151996]

93. Strait RT, Mahler A, Hogan S, Khodoun M, Shibuya A, Finkelman FD. Ingested allergens must be absorbed systemically to induce systemic anaphylaxis. J Allergy Clin Immunol. 2011; 127:982-9. e1. [PubMed: 21354602]

94. Kucuk ZY, Strait R, Khodoun MV, Mahler A, Hogan S, Finkelman FD. Induction and suppression of allergic diarrhea and systemic anaphylaxis in a murine model of food allergy. $\mathrm{J}$ Allergy Clin Immunol. 2012; 129:1343-8. [PubMed: 22465213]

95. Rupa P, Mine Y. Oral immunotherapy with immunodominant T-cell epitope peptides alleviates allergic reactions in a Balb/c mouse model of egg allergy. Allergy. 2012; 67:74-82. [PubMed: 21950267]

96. O'Shea JJ, Paul WE. Mechanisms underlying lineage commitment and plasticity of helper CD4+ T cells. Science. 2010; 327:1098-102. [PubMed: 20185720] 
97. Zheng Y, Chaudhry A, Kas A, deRoos P, Kim JM, Chu TT, Corcoran L, Treuting P, Klein U, Rudensky AY. Regulatory T-cell suppressor program co-opts transcription factor IRF4 to control TH2 responses. Nature. 2009; 458:351-6. [PubMed: 19182775]

98. Chaudhry A, Rudra D, Treuting P, Samstein RM, Liang Y, Kas A, Rudensky AY. CD4+ regulatory T cells control TH17 responses in a Stat3-dependent manner. Science. 2009; 326:98691. [PubMed: 19797626]

99. Lohning M, Hegazy AN, Pinschewer DD, Busse D, Lang KS, Hofer T, Radbruch A, Zinkernagel RM, Hengartner H. Long-lived virus-reactive memory T cells generated from purified cytokinesecreting T helper type 1 and type 2 effectors. J Exp Med. 2008; 205:53-61. [PubMed: 18195073]

100. Kim BS, Kim IK, Park YJ, Kim YS, Kim YJ, Chang WS, Lee YS, Kweon MN, Chung Y, Kang CY. Conversion of Th2 memory cells into Foxp3+ regulatory T cells suppressing Th2-mediated allergic asthma. Proc Natl Acad Sci U S A. 2010; 107:8742-7. [PubMed: 20421479]

101. Miyara M, Yoshioka Y, Kitoh A, Shima T, Wing K, Niwa A, Parizot C, Taflin C, Heike T, Valeyre D, Mathian A, Nakahata T, Yamaguchi T, Nomura T, Ono M, Amoura Z, Gorochov G, Sakaguchi S. Functional delineation and differentiation dynamics of human CD4+ T cells expressing the FoxP3 transcription factor. Immunity. 2009; 30:899-911. [PubMed: 19464196]

102. Hoffmann P, Eder R, Boeld TJ, Doser K, Piseshka B, Andreesen R, Edinger M. Only the CD45RA+ subpopulation of CD4+CD25high T cells gives rise to homogeneous regulatory T-cell lines upon in vitro expansion. Blood. 2006; 108:4260-7. [PubMed: 16917003]

103. Hansmann L, Schmidl C, Kett J, Steger L, Andreesen R, Hoffmann P, Rehli M, Edinger M. Dominant Th2 differentiation of human regulatory T cells upon loss of FOXP3 expression. $\mathrm{J}$ Immunol. 2012; 188:1275-82. [PubMed: 22210907]

104. Wilson DR, Lima MT, Durham SR. Sublingual immunotherapy for allergic rhinitis: systematic review and meta-analysis. Allergy. 2005; 60:4-12. [PubMed: 15575924]

105. Gidaro GB, Marcucci F, Sensi L, Incorvaia C, Frati F, Ciprandi G. The safety of sublingualswallow immunotherapy: an analysis of published studies. Clin Exp Allergy. 2005; 35:565-71. [PubMed: 15898976]

106. Scadding GW, Shamji MH, Jacobson MR, Lee DI, Wilson D, Lima MT, Pitkin L, Pilette C, Nouri-Aria K, Durham SR. Sublingual grass pollen immunotherapy is associated with increases in sublingual Foxp3-expressing cells and elevated allergen-specific immunoglobulin G4, immunoglobulin A and serum inhibitory activity for immunoglobulin E-facilitated allergen binding to B cells. Clin Exp Allergy. 2010; 40:598-606. [PubMed: 20184605]

107. Ciprandi G, De Amici M, Tosca MA, Pistorio A, Marseglia GL. Sublingual immunotherapy affects specific antibody and TGF-beta serum levels in patients with allergic rhinitis. Int J Immunopathol Pharmacol. 2009; 22:1089-96. [PubMed: 20074473]

108. Allam JP, Wurtzen PA, Reinartz M, Winter J, Vrtala S, Chen KW, Valenta R, Wenghoefer M, Appel T, Gros E, Niederhagen B, Bieber T, Lund K, Novak N. Phl p 5 resorption in human oral mucosa leads to dose-dependent and time-dependent allergen binding by oral mucosal Langerhans cells, attenuates their maturation, and enhances their migratory and TGF-beta1 and IL-10-producing properties. J Allergy Clin Immunol. 2010; 126:638-45. e1. [PubMed: 20584546]

109. Ganeshan K, Bryce PJ. Regulatory T cells enhance mast cell production of IL-6 via surfacebound TGF-beta. J Immunol. 2012; 188:594-603. [PubMed: 22156492]

110. Hershko AY, Suzuki R, Charles N, Alvarez-Errico D, Sargent JL, Laurence A, Rivera J. Mast cell interleukin-2 production contributes to suppression of chronic allergic dermatitis. Immunity. 2011; 35:562-71. [PubMed: 21982597]

111. Galli SJ, Grimbaldeston M, Tsai M. Immunomodulatory mast cells: negative, as well as positive, regulators of immunity. Nat Rev Immunol. 2008; 8:478-86. [PubMed: 18483499]

112. Rivera J, Gilfillan AM. Molecular regulation of mast cell activation. J Allergy Clin Immunol. 2006; 117:1214-25. quiz 26. [PubMed: 16750977]

113. Nakano H, Free ME, Whitehead GS, Maruoka S, Wilson RH, Nakano K, Cook DN. Pulmonary CD103+ dendritic cells prime Th2 responses to inhaled allergens. Mucosal Immunol. 2012; 5:53-65. [PubMed: 22012243] 
114. Halim TY, Krauss RH, Sun AC, Takei F. Lung natural helper cells are a critical source of Th2 cell-type cytokines in protease allergen-induced airway inflammation. Immunity. 2012; 36:45163. [PubMed: 22425247]

115. Price AE, Liang HE, Sullivan BM, Reinhardt RL, Eisley CJ, Erle DJ, Locksley RM. Systemically dispersed innate IL-13-expressing cells in type 2 immunity. Proc Natl Acad Sci U S A. 2010; 107:11489-94. [PubMed: 20534524]

116. Zimmer A, Bouley J, Le Mignon M, Pliquet E, Horiot S, Turfkruyer M, Baron-Bodo V, Horak F, Nony E, Louise A, Moussu H, Mascarell L, Moingeon P. A regulatory dendritic cell signature correlates with the clinical efficacy of allergen-specific sublingual immunotherapy. J Allergy Clin Immunol. 2012; 129:1020-30. [PubMed: 22464673]

117. Abrahamsson TR, Jakobsson HE, Andersson AF, Bjorksten B, Engstrand L, Jenmalm MC. Low diversity of the gut microbiota in infants with atopic eczema. J Allergy Clin Immunol. 2012; 129:434-30. [PubMed: 22153774]

118. Nagano Y, Itoh K, Honda K. The induction of Treg cells by gut-indigenous Clostridium. Curr Opin Immunol. 2012 Jun 4. Epub ahead of print.

119. Hanski I, von Hertzen L, Fyhrquist N, Koskinen K, Torppa K, Laatikainen T, Karisola P, Auvinen P, Paulin L, Makela M, Vartiainen E, Kosunen TU, Alenius H, Haahtela T. Envionmental biodiversity, human microbiota, and allergy are interrelated. Proc Natl Acad Sci USA. 2012; 109:8334-39. [PubMed: 22566627]

120. Kawakita A, Shirasaki H, Yasutomi M, Tokuriki S, Mayumi M, Naiki H, Ohshima Y. Immunotherapy with oligomannose-coated liposomes ameliorates allergic symptoms in a murine food allergy model. Allergy. 2012; 67:371-9. [PubMed: 22423374] 


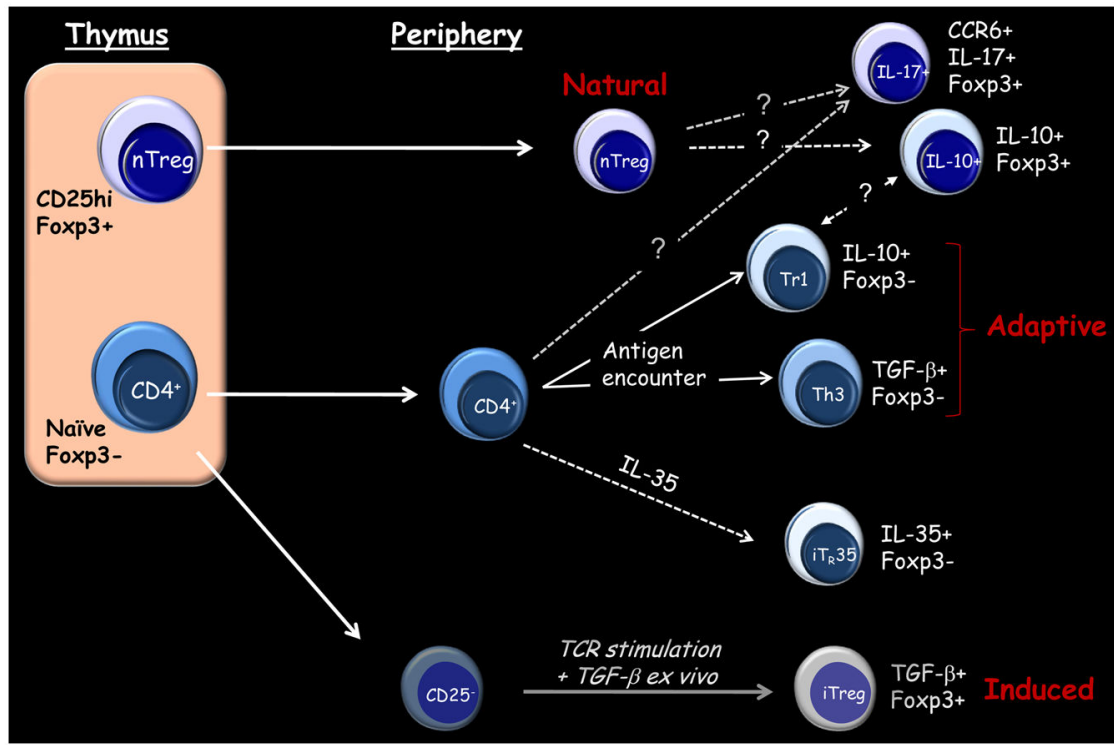

Figure 1. Types of $\mathbf{T}$ Regulatory Cells Implicated in Suppressing Inflammatory Responses Dashed lines indicate unresolved aspects of Treg cells in humans. See text for details. 


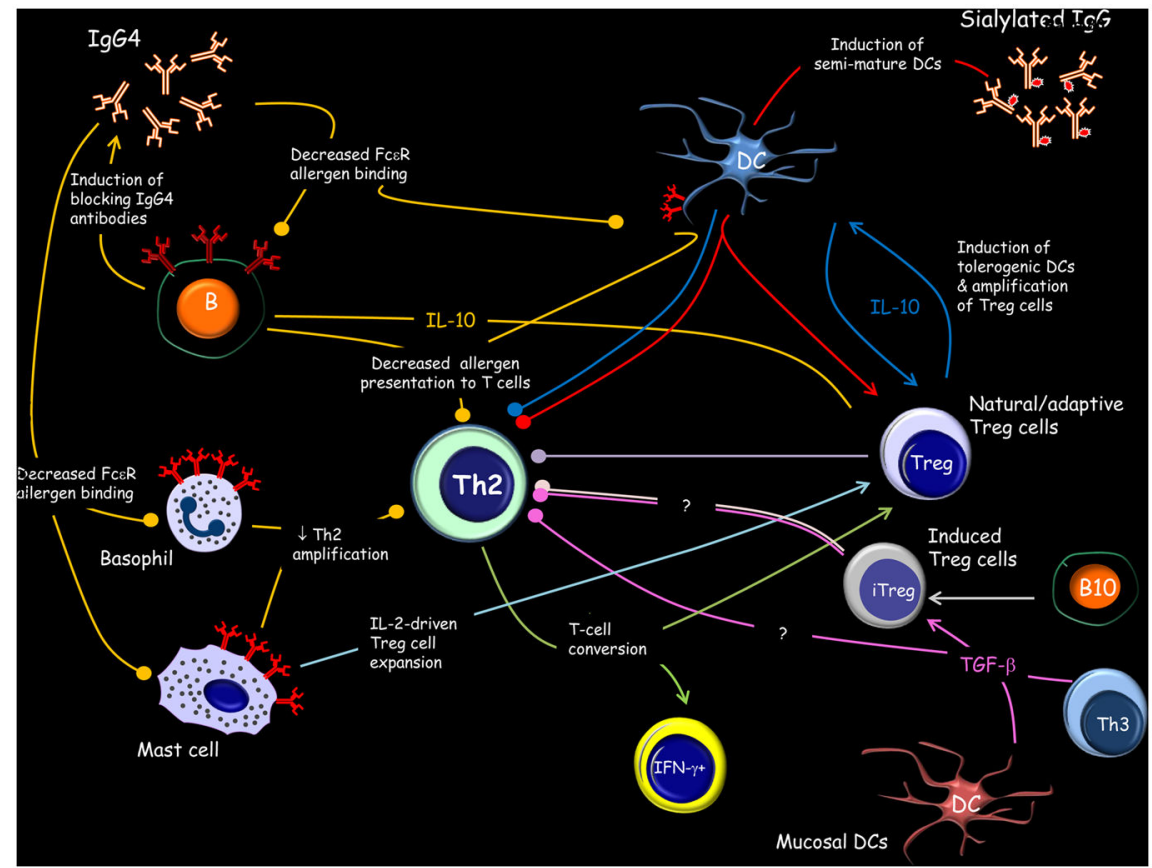

Figure 2. Regulatory Networks and the Allergic Response

Multiple pathways operate to suppress Th2-driven allergic inflammation in allergen tolerance. The relative contribution of induced Treg cells and Th3 cells remains unresolved. Colored lines denote afferent and efferent arms of the same pathway. Circles denote inhibitory pathways. See text for details. 